\title{
PRIVATE AFFAIRS, PUBLIC OFFICE: \\ READING THE BODY OF VIRGÍLIA IN THE POSTHUMOUS MEMOIRS OF BRÁS CUBAS
}

\author{
Apsara Iyer \\ Yale University \\ New Haven, CT, USA \\ Kenneth David Jackson ${ }^{* *}$ \\ Yale University \\ New Haven, CT, USA
}

\begin{abstract}
As Machado de Assis's The Posthumous Memoirs of Brás Cubas (1881) reflects on the life of a single man, two dominant forces emerge within the narrative: Brás Cubas's desire for a family and his quest for political office. These parallel efforts coincide in the form of the political wife, the woman who enables both domestic and public glory. Using the encounter of public and private spaces as a point of departure, this essay considers female forms as circumscribed by their private and public duties. Evaluating Virgília and Marcela, we explore the significance of materiality and promiscuity in the reading of women's bodies within the text.
\end{abstract}

Keywords: Machado de Assis; feminism; body politic; public versus private; women.

In 1588, writing on the women of her casas pias, Magdalena de San Gerónimo declared that much of the harm caused to empires came from the liberty and vagrancy of individual women ${ }^{1}$. As both the founder of casas pías for "fallen women," or prostitutes, and a dealer in relics of beatified virgins, Magdalena de San Gerónimo strikes at the tension between the materiality of the female form and its exaltation, between the corruption of an individual body and the body politic. Magdalena's work serves to visualize the conflict at play within The Posthumous Memoirs of Brás Cubas, where the bodies of Virgília and Marcela offer twin reflections on the "imagined" saint and the "material" public woman. As the wife deferred, the woman intended to be Brás Cubas's betrothed and then promised to another man,
Virgília emerges in contrast to the image of Marcela, Bras's liberal Spanish mistress who befriends many a young man. As the novel progresses, the grotesque pockmarks of Marcela's pox-ridden skin stand against the ever-luminous flesh of Virgília. The single Marcela, with her rotation of suitors, represents a "public" woman in contrast to Virgília's idealized, private domestic form. The intersection then, between the real and the idealized, the public and the private, appears in its fullest expression in the link between public office and private intimacies. The perfect wife, advanced first by Brás Cubas's father, offers a metonymy for political ambition-a fervent private desire to conquer a public space. It is here that we observe the true significance of Virgília's body, as a suggestive tableau for a larger entity-the body politic.

\footnotetext{
* Apsara Iyer is a student of Spanish \& Economics and Math at Yale University. Her research interests are in colonial chronicles, the Baroque in Latin America, market formation and the body politic. Her email is: apsara.iyer@yale.edu.

${ }^{* *}$ Kenneth David Jackson is Professor of Portuguese at Yale University. He specializes in Portuguese and Brazilian literatures, modernist movements in literature and other arts, Portuguese literature and culture in Asia, poetry, music, and ethnography. He has conducted field research in Sri Lanka and India, was a Fulbright lecturer and researcher in Brazil $(1984,1990-91)$ and performed as a cellist in several professional orchestras and a string quartet.
} 
Our contemplation of sexuality and the body politic considers distinct themes treated in existing literary criticism. The relationship between the materiality of the female form and its representative capacity emerges in the work of Amy Kaminsky (1993), who has evaluated the way in which distinct Latin American regions asserted national brands of feminism through the space of the female body. Karen Sanchez-Eppler (1993) has also examined the relationship between female bodies and the body politic, analyzing the reconstruction of antebellum America's "body politic" through the women's suffrage movement. The manifestation of a national consciousness through women's liberation movements within the Brazilian Republic appears central to Earl E. Fitz's readings in Machado de Assis and Female Characterization. While Fitz uses a longrange analysis of the evolution of Machado's female protagonists over the course of his oeuvre, our reading examines a single figure. Rather than making a general claim about the casual relationship between all female bodies and the state, as Kamensky and Sanchez-Eppler do, we focus instead on a specific subset of women, those who enter a public domain through their marriage with a political figure. In doing so our efforts center on understanding the fundamental question of why Virgília-feted and secure-might choose to enter an illicit affair with Brás.

Our first reading of the female body lies in its twin representations-at once grotesquely realistic and abstract. In a hyper-real rendering, Brás Cubas focuses on concrete details about Marcela, involving her physical form and possessions. The descriptions are unforgiving and realistic, her flaws and imperfections rendered in high relief. Brás's relationship with Marcela emerges through the goods he presents her-that first "something in silk," or "piece of jewelry." A small collection of treasures comes to stand in for any details about "Marcela." It is the "ancient gold doubloons," the "carved jacaranda furniture," the "beautiful plate from India,"-the various "spoils from her loves of other times"-that grow to define her (Brás Cubas 36). Any insight into her temperament stems from her interactions with these trinkets, the sense of how "she examined it between her fingers, looking for the best light, trying it on, laughing, and kissing me with an impetuous obstinacy" (Brás Cubas 36). Brás Cubas's later interactions with Marcela continue to ground her in the domain of the mortal and material, as she appears aged and diseased. The details he observes do not "abstractly" portray her as ever youthful, but rather ridden with "marks, large and plentiful, formed bumps and notches up and down her face and they gave the feeling of sandpaper, enormously thick" (Brás Cubas 70). The nauseating detail is punctuated by descriptions of her grey hair, highlighting her very human flaws. The final detail that allows Brás Cubas to identify her is a "diamond [that] gleamed on one of her fingers of her left hand" (Brás Cubas 70). The crucial detail further underscores her representation through tangible, material possessions.

In contrast, Virgília appears possessed by an indescribable allure that extends far beyond her physical form. Brás Cubas's descriptions move beyond her physical presence to center on an intangible essence, the sense "she came from the hands of nature full of that sorcery, uncertain and eternal, that an individual passes to another individual for the secret ends of creation" (Brás Cubas 57). He continues to emphasize this sense of "sorcery" as he concludes she is "full of mysterious drives" (Brás Cubas 57). When he finally imagines seeing her smallpox ridden, the representation deviates from the presentation of the same affliction in Marcela. He writes, "Her skin, so delicate and pink and pure before, just a day ago, looked yellow to me now, stigmatized by the same lash that had devastated the Spanish woman's face. Her eyes, which used to be lively were dull, her lips were sad and she had a weary air about her" (Brás Cubas 74). With the end of Brás's double vision, gone is the excruciating examination of the ridges and crevasses of a pockmarked cheek, replaced by a reference to the memory of Virgília's unmarked flesh. The details center on her spirit, now weary, rather than the "dusty hair" and physical signs of old age that Brás Cubas noted in Marcela. Virgília appears surrounded by an aura of perfection, a sense of growing ever finer with age, an idealized mystery.

The division between realistic and idealized assumes additional significance as we examine 
the second reading the female body, as a space circumscribed by public and private intimacies. Brás associated his first sight of Marcela with a public celebration. He recalls, "I saw her for the first time on the Rossio Grande, a night of fireworks celebrating the declaration of independence, a springtime festival, the dawn of the public soul" (Brás Cubas 34). From this first viewing, his initial attraction to Marcela appears in the perception of her promiscuity, as he notes, "I saw her get out of a sedan chair, graceful and eyecatching, a slim, swaying body, elegant-something I'd never found in chaste women" (Brás Cubas 34). $\mathrm{He}$ enters into a relationship with Marcela with a clear acknowledgment of her other suitors, men like the "tubercular Xavier" (Brás Cubas 34). The description of the trinkets serves as a constant reminder of past loves, underscoring Marcela's independence from appearing tied to a singular man. Her prevailing characteristic is that she is not a "chaste" woman.

In contrast, Virgilia initially seems inextricably linked to the notion of chastity. She enters the story a "pretty, fresh," figure, the answer to Brás Cubas's father's question about whom he should marry (Brás Cubas 34). From that foundation, her character offers the consummate representation of monogamy. She is neither accessible nor immediately obliging. Once she is married, attraction to her still takes on a refined edge. She appears impassive and apart from the crowd, like "one of those figures carved in Pentelic marble, of noble workmanship, open and pure" (Brás Cubas 100). Lobo Neves reinforces the sense of Virgilia's identity as a wife by heralding her the paragon of domesticity. Brás Cubas notes, "He never tired of telling me how he loved his wife. He thought that Virgília was perfection itself, a combination of solid and refined qualities, loving, elegant, austere, a model woman" (Brás Cubas 93). The perception of her marble austerity stands in start contrast to the warm Marcela, glibly collecting strings of suitors alongside her jeweled baubles.

Yet despite her initial reserve and austerity, Virgília’s interaction with politics transforms her into a creature of public enjoyment; she is a saleable good whose status and beauty prepare her for a "public" consumption. Though she typifies a domestic, intimate relationship, her role as the wife of a political figure makes her part of the public domain. From the beginning, Brás Cubas's father advances that the space of the home of a political man parallels that of "public office." Virgília offers an answer to Brás Cubas's father's premonition that "bride and parliament are the same thing" (Brás Cubas 58). His father dismisses his idea that one "can be a married man and a public man separately" (Brás Cubas 58). His father instead argues that "[a]ll public men have to be married” (Brás Cubas 58). Virgília’s duties, waltzing with fellow guests and maintaining appearances at operas, transform her body into an object of collective desire. As Brás Cubas imagines Virgília in box seats at the Candiani opera, the scene marks the collision of public fascination and individual possession. Brás Cubas describes,

I could see her from there, reclining in her box with her magnificent arms bare-the arms that were mine, only mine-fascinating everyone's eyes with the superb dress she must have had on, her milky white breast, her hair in tight curls in the style of the time, and her diamonds, less brilliant than her eyes... I saw her like that and it pained me that others should see her. (Brás Cubas 103)

The "pain" Brás Cubas feels represents a private intimacy stripped away by public fascination, the sense of "everyone's eyes" feasting upon something that was "mine, only mine." The cinematic description emphasizes "the style of the time," the background pressure of social mores, to emphasize those in the public audience who enjoy her exhibition-a faceless public. The vivid movement from her "arms," "breast," "hair," draws the reader along as Brás Cubas devours Virgília through the eyes of eager spectators, emphasizing the parts of her flesh left uncovered for public spectacle. As the crowds feast on Virgília, each taking pleasure from "consuming" her image, Virgília herself loses her individuality, the passive object of a public lust.

The tension between public and private lives is further complicated by Brás Cubas's affair with 
Virgília-their relationship represents a private act whose greatest threat comes from public exposure. The particular significance of "public" knowledge of their intimacies appears at countless moments. When Coltrim visits Brás Cubas, his harsh admonishment concludes that "in short, we [Virgília and Brás Cubas] were the object of public suspicion" (Brás Cubas 107). The particular inclusion of "public" in the charge serves to underscore the audience, those who care most about their affair. The immediate threat does not come from Lobo Neves or Luís Dutra but rather an undefined general audience -whispers, the furtive gossip of curious baronesses and maids. As Brás Cubas considers joining Virgília, his primary concern is whether the act would be "an insane exposure of Virgília's reputation" (Brás Cubas 122). The concern for "reputation" highlights the importance of public perception for the couple's relationship. The perception is directly tied to the transmission of information about their acts and whereabouts. When Lobo Neves receives an anonymous letter about the affair, the crippling information is not any individual detail about their relationship but rather the fact everyone else already knows. Brás Cubas, writes the letter, "didn't say everything. It spoke, about our intimacy and added that the suspicions were a matter of public knowledge" (Brás Cubas 141).

Politics again emerges as a confounding factor amplifying the consequences of the affair between Brás Cubas and Virgília, the repercussions of making this particular private affair public. As he warns Brás Cubas against taking a secretary position simply to be close to Virgília, Coltrim says,

Here in the capital a matter like that gets lost in the mass of people and interests. But in the provinces it takes on a different shape. And since it's a question of political people, it really is unwise. The opposition newspapers as soon as they sniff out the business, will proceed to print it in block letters, and out of that will come the jokes, the remarks, the nicknames. (Brás Cubas 125)

The emphasis that "it's a question of political people" underscores the role of politics in heightening general curiosity about private lives. Space of the public office cedes any privacy to public opinion, just as Virgília's role cedes her body to a public view. The role of public opinion in political considerations, the manipulations of "opposition newspapers" is further emphasized as Brás Cubas begins considering the difficult lesson he has been taught on the importance of public opinion for domestic institutions. He writes, "the conclusion, if the previous chapter has one, is that public opinion is a good glue for domestic institutions... One way or another, public opinion is a good glue, both in domestic order and in politics" (Brás Cubas 158). Public opinion thus appears as the link between the home and the state, the "domestic order" and "politics." The corrosive quality it once had to destroy relationships appears now as an edifying feature, strengthening the structure of institutions both personal and political. A similar link between private and public, personal and political, is drawn as Brás Cubas considers Lobo Neves's rejection of the provincial presidency. He writes, "the private event of the evil omen of a number produced the phenomenon of political discord" (Brás Cubas 145). Here, individual superstitions form larger trends, patterns of political fragmentation.

The notion of "possessing" Virgília, the ideal governor's wife, grows synonymous with obtaining political success, while failure to make her one's own parallels defeat. Virgília's particular role in facilitating political success appears clear when Brás Cubas's father says, "As for the bride-that's the name I give to a lovely creature who's a jewel, a flower, a star, something rare... She's his daughter. I imagined that if you married her you'd get to be a deputy quicker" (Brás Cubas 68). The specific notion of "possessing" Virgília is advanced first by Brás Cubas when he reflects on his father's advice to find a wife and a position. He writes, "One part of me said yes, that a beautiful wife and a political position were possessions worthy of appreciation" (Brás Cubas 55). The sense of "appreciation" underscores the role of public opinion in the pursuit of these "possessions." As Lobo Neves reflects on his wife's perfection, he decides that "he needed public glory" (Brás Cubas 93). Brás Cubas, too, is compelled to politics following time spent around a married Virgília. After he leaves her 
house, he notes that "politics must be an invigorating wine," before remarking, "Why can't I be a minister?" (Brás Cubas 94). As the memoirs progress, the failure to make Virgília "mine, only mine" parallels political disappointments. Brás Cubas acknowledges this after he does not marry Virgília, writing, "Lobo Neves' candidacy was backed by people of great influence. I gave in. Such was the start of my defeat. A week later Virgília asked Lobo Neves, smiling, when he was going to be a cabinet minister" (Brás Cubas 76). Later, when Brás Cubas meets Virgília following her marriage, the chapter, "The Old Dialogue of Adam and Eve" winds through a conversation:

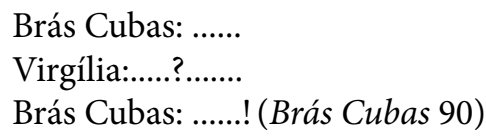

The dialogue parallels the Chapter CXXXIX, "“'How I didn't Get to be a Minister of State," which reads, ". .." (Brás Cubas 183).

Brás Cubas later explains the text, writing that "there are things better said in silence" (Brás Cubas 184). The pairing of these two episodes through their similar use of punctuation highlights the link between a personal and a political defeat. The two chapters stand apart from the rest of their text with their self-conscious silence, breaks in the narrative that add significance by underscoring that which is not said. Brás Cubas's inability to fulfill his desire to make Virgília "mine, only mine" parallels his failure to achieve a lasting political position. Belaboring the parallel between the personal and political one moment further, we find Virgília's miscarriage cast in a new light. Brás's inability to father a son effectively reflects the absence of a political successor, an often-hereditary effort. This sense appears clearly, as Brás Cubas's father explains his motivation for finding a bride and a seat in Parliament for his son, saying, "Our name has to continue; continue it and make it shine even more" (Brás Cubas 58). The miscarriage, a crippling personal defeat, is amplified only by this secondary consequence.

In the theater of the public and the private, the domain of the wife and the mistress, we find ourselves contemplating a singular woman who holds the capacity to engender presidents and destroy budding politicians: Virgília-the figure at once the object of public and private fascination. Marriage to Virgília by a budding politician signals a larger victory, a broader political success. The mythic body of Virgília, surrounded by domestic and political "institutions" thus is a specter of a larger body, the government. It is here where the three displacements of the private, public, and political intersect in the form of the ideal candidate's wife. This particular female figure appears at once the symbol of monogamy, public fascination, and political success. Desire colors the three spaces, as the body of Virgília, the body of the state, is the subject both of private and public quests for possession. It is here where we find both the hoarding of virgin relics and the administration of poorhouses for prostitutes-the essence of Magdalena de San Geronimo. It is here where we observe the interplay between a perceived private woman and her public fetish, her private intimacies and her public responsibilities. It is here where love for a nation and the love of a nation emerge consummated in a physical form. It is here where we find Brás Cubas concluding, at last, "only great passions are capable of great actions" (Brás Cubas 101).

\section{Notes}

1. Georgina Dopico Black, "Public bodies, private parts: The virgins and Magdalens of Magdalena de San Gerónimo," Journal of Spanish Cultural Studies, Vol. 2, No. 1 (2001), 81-82.

\section{References}

Dopico Black, Georgina, "Public Bodies, Private Parts: The Virgins and Magdalens of Magdalena de San Gerónimo". Journal of Spanish Cultural Studies. 2. 1. (2001): 81-82.

Fitz, Earl. Machado de Assis and Female Characterization: the Novels. Lewisburg: Bucknell University Press, 2015.

Kaminsky, Amy. Reading the Body Politic: Feminist Criticism and Latin American Women Writers. Minneapolis: University of Minnesota Press, 1993.

Machado de Assis, Joaquim Maria. The Posthumous Memoirs of Brás Cubas. Trans. Gregory Rabassa. New York: Oxford University Press, 1997. 
Sanchez-Eppler, Karen. Touching Liberty: Abolition, Feminism, and the Politics of the Body. Berkeley: University of California Press, 1993.

Recebido em: 01/06/2015 Aceito em: 13/09/2015 